\title{
POLITICO-ISLAMIC ISSUES IN MALAYSIA IN 1999
}

\author{
By: Ibrahim Abu Bakar
}

Abstrak

Tulisan ini merupakan kajian singkat sekitar isu politik Islam di Malaysia tahun 1999. Pada Nopember 1999, Malaysia menyelenggarakan pemilihan Federal dan Negara Bagian yang ke-10. Titik berat tulisan ini ada pada beberapa isu politik Islam yang dipublikasikan di koran-koran Malaysia yang dilihat dari perspektif partai-partai politik serta para pendukungnya. Partai politik di Malaysia cukup banyak, dan di sini diangkat empat partai politik yaitu: Organisasi Nasional Malaysia Bersatu (UMNO), Asosiasi Cina Malaysia (MCA), Partai Islam Se-Malaysia (PMIP atau PAS) dan Partai Aksi Demokratis (DAP). UMNO dan MCA adalah partai yang berperan dalam Barisan Nasional (BA) atau Front Nasional (NF). PAS dan DAP adalah partai oposisi pada Barisan Alternatif (BA) atau Front Alternatif $(A F)$. PAS, UMNO, DAP dan MCA memiliki pandangan tersendiri tentang isu-isu politik Islam. Adanya isu-isu politik Islam itu pada dasarnya tidak bisa dilepaskan dari latar belakang sosio-religitus dan historis politik masyarakat Malaysia.

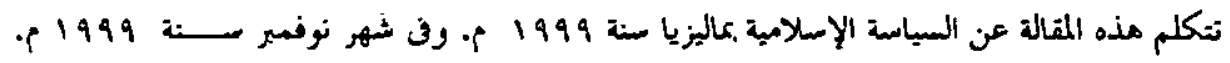

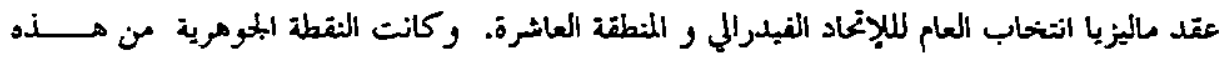

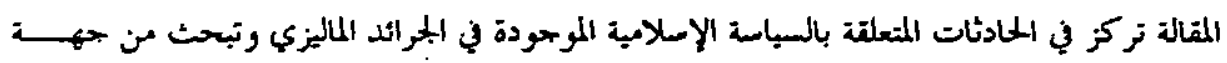

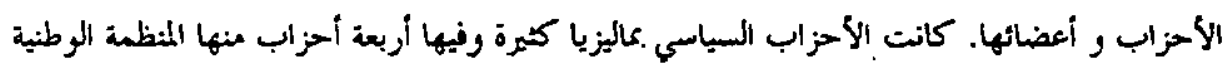

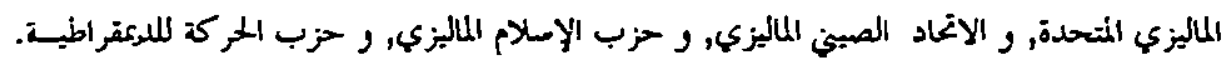

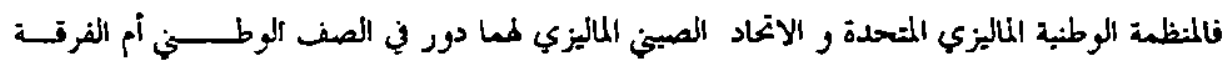

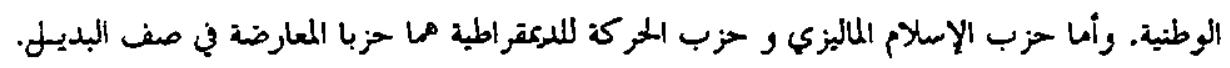

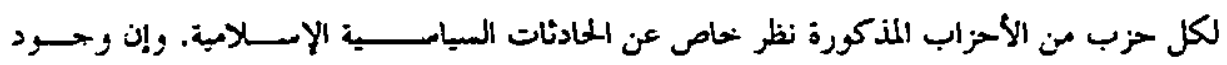

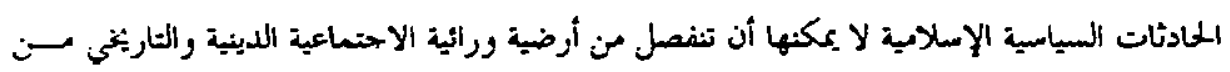
سياسة المجتهع الماليزي. 


\section{A. Preface}

This paper is a short discussion on politico-Islamic issues in Malaysia in 1999. In November 1999 Malaysia held her tenth federal and state elections. The paper focuses on some of the politico-Islamic issues which were published in the Malaysian newspapers from the perspectives of the political parties and their leaders or supporters. The political parties in Malaysia are innumerable and this paper refers to four political parties namely the United Malays National Organization (UMNO), Malaysian Chinese Association (MCA), Pan-Malaysian Islamic Party (PMIP or PAS) and Democratic Action Party (DAP). UMNO and MCA are the ruling parties in Barisan Nasional (BN) or the National Front (NF). PAS and DAP are the opposition parties in Barisan Alternatif (BA) or the Alternative Front (AF). PAS, UMNO, DAP and MCA were reported to have their own views on the politico-Islamic issues. To have a clearer picture about the politico-Islamic issues in Malaysia in 1999, it is important to briefly survey Malaysian socio-religious and politico-historical backgrounds.

\section{B.Malaysian Socio-religious Background}

Socially and religiously Malaysian society is made up of different ethnic groups and religions. It is a multi-ethnic and multi-religious nation. There are Malays whose religion is Islam according to Malaysian constitution. Other main ethic groups are Chinese, Indians, and Natives. The Natives in Malaysia are the natives of Sabah, Sarawak, and Malay Peninsula or Malaya. The Malay word nBumiputerao is used to refer to the Malays and the Natives in Malaysian economic perspective. Other religions in Malaysia are Christianity, Buddhism, Hinduism, Animism, Confucianism, Taoism, and Sikhism.

nIslam was the most widely professed religion in Malaysiat . In 1991, some 10.3 million persons belonged to this faith, consisting 59 per cent of the total population. This represents an increase of 6 percentage points over the 1980-1991 period. ${ }^{1}$ In 1991, there were some 3.3. million Buddhists and some 1.4 million Christians in Malaysia. The percentage of Buddhists and Christians rose from 17.3 and 6.4 percent in 1980 to 18.4 and 8.1 percent respectively in $1991 .{ }^{2}$ Muslims formed the majority of the population in most states in Malaysia. The states with the largest Muslim proportion were Kelantan and Terengganu with 94 and 95 percent respectively in 1991. The largest proportion of Buddhists in Malaysia was in Penang and the Federal Territory of Kuala Lumpur; they were about 34 percent. The largest

\footnotetext{
' Department of Statistics Malaysia, 1995, Laporan An Banci Penduduk (General Report of the Population Census), Vol. 1 Kuala Lumpur, hal. 72

${ }^{2}$ Ibid., hal. 72
} 
proportion of Christians in Malaysia was in Sabah and Sarawak, and they formed 37 and 27 percent of the total populations of Sabah and Sarawak respectively in 1991. ${ }^{3}$ The non-Muslims in Malaysia have formed "the Malaysian Consultative Council of Buddhism, Christianity, Hinduism, and Schism" which is abbreviated as $\mathrm{MCCBCHS}^{4}$.

\section{C.Malaysian politico-historical Background}

Politically Malaysia is a federated, democratic independent nation. Malaysia attained her independence from the British Government on September 16,1963 . The Federation of Malaysia consists of Malaya, Sabah, Sarawak, and Singapore. However, two years later Singapore decided to be independent from Malaysia. "On 9 August 1965 the Malaysian House of Representatives (Dewan Rakyat) passed a Constitutional Amendment Bill enabling Singapore to secede from the Federation." Thus Malaysia, after August 1965, comprised Malaya, Sabah, and Sawarak. .

Malaya, referring to Tanah Melayu which literally means the Malay land, gained her independence from the British Government on August 31, 1957. The $31^{\text {st }}$ August is remembered and celebrated as the Independent day in Malaysia every year. Malaya was the Federation of the states of Kelantan, Terengganu, Pahang, Kedah, Perlis, Perak, Selangor, Negeri Sembilan, Johor, Pulau Pinang (Penang), and Melaka (Malacca). All the states in Malaya have Malay rulers except Penang and Malacca. Both states had no longer Malay rulers after the western colonizers occupied them. Many Malay rulers in Malaya were from the Malay kingdom of Malacca. The first western power who took control over Malacca was the Portuguese in 1511 and then the Dutch who defeated the Portuguese in Malacca in 1641. The British took over Malacca from the Dutch in 1795. "Melaka continued under British rule from 1795 , except for a brief period of Dutch control from 1818 until 1824 ..." The Anglo-Dutch Treaty of 1824 legitimized the British occupation and rule of Malacca and Singapore. ${ }^{6}$

Under the British rule, Malaya was divided into three administrative units namely the Federated Malay States (FMS), the Unfederated Malay States (UMS), and the Straits Settlements (SS). The FMS were the states of Selangor, Perak, Pahang, and Negeri Sembilan. The UMS comprised the states of Johor, Kedah, Perlis, Terengganu, and Kelantan. The SS were Penang, Malacca and Singapore?

${ }^{1}$ Ibid., hal. 73-74

- New Sunday Times, November 28, 1999

5 Barbara Watson Andaya and Leonard Y. Andaya, 1986, A History of Malaysia, Houdmills, Macmillan Education Ltd., hal. 275

'Ibid., hal. 114

' Paul Chang Ming Phang, 1975, Perkembangan Dalam Masyarakat Berbilang Kaum Kajian Kasus Malaysia. Kuala Lumpur, Dewan Bahasa Pustaka, hal. 1-2 
The Japanese invasion and occupation of Malaya from 1942 to 1945 made the Malays aware the fact that the small eastern power, the Japanese, was able to defeat the great western power, the British. The Japanese also encouraged Malay nationalism. "In this period Malays increasingly began to see themselves as belonging to a Malay-wide entity, rather than to.their individual states." 8 In July 1945 the Japanese in Malaya openly supported and promoted the formation of a new political and nationalist organization named Kesatuan Rakyat Indonesia Semenanjung (KRIS) led by Ibrahim Yaakub and Dr. Burhanuddin Al-Helmy. The main aim of the organization was to unite Malaya and Indonesia, which were under the Japanese rule. However, the organization abruptly came to an end after the Japanese surrender to the British in Malaya on August 15, 1945. ${ }^{9}$

The Malays in Malaya began to protest against the British political and administrative plan to establish a Malayan Union, which intended to provide the equal rights and opportunities to all races living in Malaya under the British rule. There were two Malay political parties formed before 1957 and both parties have survived to the present time. The first party is the United Malays National Organization (UMNO), formed in 1946, to fight against the proposed Malayan Union. UMNO was led by 'Onn Ja' afar from its founding in 1946 until 1951, and by Tunku Abdul Rahman from 1951 to 1970. The initial success of the party among the Malays was due to its ability to harness Malay opinion in the fight against the Malayan Union." 10

Tunku Abdul Rahman was asked to step down from being the leader of UMNO after the ethnic disturbances took place on May 13, 1969 in Kuala Lumpur, Penang, and Ipoh. Tun Abdul Razak Hussein led UMNO until his death in January 1976. "His death on 14 January 1976 arose some fears that the new leadership would be less successful in balancing conflicting groups within UMNO and the society at large." "Hussein Onn, the son of the first UMNO leader, led UMNO until his resignation in July 1981. "In July 1981 Tun Hussein Onn formally resigned as Prime Minister of Malaysia following a slow recovery from complicated heart surgery. He was succeeded by former UMNO 'radical', Dato Seri Dr. Mahathir bin Mohamad."'2

All UMNO national leaders, except its first leader, are also the Prime Ministers of Malaysia. Hence, UMNO dominated Malayan and Malaysian politics. The special edition of Utusan Malaysia, a Malay daily newspaper, was issued on May 11, 1996 in conjunction with the celebration and com-

"Barbara Watson Andaya and Leonard Y. Andaya, op. cit., hal. 248

"Ibid., hal. 250

in Ibid., hal. 266

"Ibid., hal. 293-294

12 Diane K. Mauzy, 1986, "The 1982 General Election in Malaysia: A Mandate for Change?, in Readings in Malaysia Politics, ediced by Bruce Gale, Petaling Jaya, Peladuk Publication, hal. 3 
memoration of UMNO 50 years old. It portrayed and honored Tunku Abdul Rahman as Bapa Kemerdekaan (the Father of Independence), Tun Abdul Razak as Bapa Pembangunan (the Father of Development), Tun Hussein as Bapa Keamanan (the Father of Peace), and the present Dr. Mahathir Mohamad as Bapa Malaysia Moden (the Father of Modern Malaysia).

Another political party formed by the Malays in Malaya before 1957 was the party based on the religion of Islam by the name Persatuan Islam Se Malaya (PAS) or the Pan-Malayan Islamic Party (PMIP). It was registered on June 15, 1955. In December 1958 the name of the party was called Persatuan Islam Se Tanah Melayu (PAS) or the Pan-Malay Land Islamic Union, and later on in 1971 it was changed to Parti Islam Se Malaysia (PAS) or the Pan-Malaysian Islamic Party (PMIP). ${ }^{13}$

UMNO was able to become the ruling party in Malaya because it had formed the political alliance with the Chinese and Indian political parties, namely the Malayan Chinese Association (MCA) and the Malayan Indian Congress (MIC). The representatives from UMNO, MCA and MIC were invited by the British Government to negotiate the terms and conditions for an independent Malaya, which was, declared independence on August 31, 1957. In every general election in Malaya, UMNO, MCA, and MIC entered the elections with the name Parti Perikatan (PP) or the Alliance Party (AP) whose symbol was Kapal Layar or the sailing boat. The symbol of PAS was Bulan dan Bintang or the Moon and the Star and then Bulan Purnama Putih or the White Full Moon.

In order to accommodate more political parties especially those from Sabah and Sarawak, the Alliance Party was changed to Barisan Nasional (BN) or the National Front (NF) in October 1974 and the new symbol Dacing or the scale of justice replaced the sailing boat symbol of the Alliance Party. In October 1999, BN celebrated its 25 years old. BN has 14 political parties, the largest is UMNO and the second large is MCA. GERAKAN is another Chinese party in BN. ${ }^{14}$ GERAKAN is very influential in Penang. The Penang Chief Minister is GERAKAN. According to the MCA secretary general Dr. Ting Chew Peh, "The MCA has projected its membership to hit the one million mark by the end of the year. ${ }^{15}$ However, unlike GERAKAN, the MCA members are not appointed to become the Chief Minister or Menteri Besar in any state in Malaysia.

\footnotetext{
[. Safie Bin Ibrahim. 1981. The Islamic Pary of Maloysia: Its Formative Srages and Ideology, Pasir Pureh, Kelantang, Nuawi bin Ismail. hal. 62-63

${ }^{14}$ Ususan Maloysia. Oct. 23,1999

is Sunday Star. April 2, 2000
} 
PAS was supported for "its appeal to Islam as the basis of a Malaydominated society and in its demands for the preservation of Malay privileges. The principal PAS stronghold has been in Kelantan and Terengganu, two states with the highest national percentage of Malays and with some of the lowest levels of modern economic development." 16

In the 1990 Malaysian general elections, PAS won 7 Parliamentary seats and 32 State seats. For the 1995 Malaysian general elections, PAS gained 7 Parliamentary seats and 33 State seats. ${ }^{17}$ The tenth Malaysian general elections, which took place on November 29, 1999, granted PAS the power to rule Kelantan and Terengganu and to win 27 parliamentary seats. PAS was also able to win few Parliamentary and States seats in Kedah, Pahang, Perak and Perlis. ${ }^{18}$ It was the largest Parliamentary and State seats given by the Malaysian voters to PAS. Thus, the PAS President, Datuk Fadzil Noor, was appointed the Opposition Leader in the Malaysian Parliament by the opposition parties. He took over the post from Lim Kit Siang who had been the Opposition Leader since 1978. Lim was from DAP. "Currently, the Opposition Leader is provided an office in Parliament House, a RM2,000 monthly allowance, and a place in the Select Committee which appoints MPs to the various sub-committees of the Dewan Rakyat." "I9 In Kelantan, UMNO was able to win only one Parliamentary seat and two State seats in the 1999 general elections. The Parliamentary seat was Gua Musang, secured by Tengku Razaleigh Hamzah. He had been appointed the National Front leader for Kelantan few months before the general elections. He was the national leader of Parti Melayu Semangat 46 (S46) or the 46 Malay Spirit Party during the 1990 and 1995 Malaysian general elections. In both elections, PAS worked together with S46 to defeat BN in Kelantan. Tengku Razaleigh Hamzah had unsuccessfully challenged Dr. Mahathir in the 1987 UMNO general election for the post of UMNO President. S46 claimed that UMNO under the leadership of Dr. Mahathir had deviated from the UMNO original spirit of the 1946. However, Tengku Razaleigh gave up S46 and dissolved the party on October 6, 1996 and many members of S46 including Tengku Razaleigh joined UMNO. ${ }^{20}$ S46 won 6 Parliamentary seats and 12 State seats in Kelantan in the 1995 general elections. S46 took part in the general elections for the first time in 1990 and won 8 Parliamentary seats and 19 State seats. ${ }^{21}$

Democratic Action Party (DAP) claims that it is a multi-ethnic political party but many Malaysians consider it as a Chinese opposition party. It won

\footnotetext{
${ }^{16}$ Barbara Watson Andaya and Leonard Y. Andaya, op. cit., hal. 267

17 Utusan Malaysia, 27 April 1995

.18 Ibid. Dec.1, 1999

${ }^{14}$ New Straits Times, Dec. 9, 1999

2) Utusan Malaysia, January 1, 2000

"Utusan Malaysia. Aprit 27, 1995
} 
9 and 10 Parliamentary seats in the 1995 and 1999 Malaysian general elections respectively. ${ }^{22}$

For the 1999 Malaysian general elections, PAS, DAP, KEADILAN (Parti Keadilan Nasional or National Justice Party) and PRM (Parti Rakyat Malaysia or the Malaysian People Party) came together to form BA (Barisan Alternatif or the Alternative Front) to struggle against $\mathrm{BN}$ or the National Front. According to Kamaruddin Jaafar, BA was officially formed on October 24, 1999 when the four opposition parties agreed to issue their own manifestos devoting to moving forward a more just Malaysia. ${ }^{23}$ The BA manifesto also promises to strengthen Malaysian economy, to upgrade administrative accountability and transparency, to establish a new social contract, to foster national solidarity, to form a genuine democracy, and to rectify Malaysian image and position on the world stage. ${ }^{24}$

In the 1999 Malaysian general elections, the number of the Parliamentary seats was 193. Out of those seats BN won 148 and BA won 42 seats respectively. Other three seats were obtained by PBS from Sabah. Among the BN parties, UMNO won 72, MCA 28, MIC 7, and GERAKAN 7 respectively. Other parties in BN secured the other seats. Among the BA parties, PAS won 27, DAP 10, and KEADILAN 5 seats respectively. ${ }^{25}$

The Islamic issues are always vividly present in the Malaysian political movements for many reasons. First, Islam is the religion of Malaysia. The Federal Constitution of Malaysia states in Article 3 as follows: "Islam is the religion of the Federation; but other religions may be practiced in peace and harmony in any part of the Federation." Secondly, the Malays are religiously and legally Muslims in the Federal Constitution of Malaysia. It says that " Malay' means a person who professes the religion of Islam, habitually speaks the Malay language, conforms to Malay custom and (a) was before Merdeka Day born in the Federation or in Singapore or born of parents one of whom was born in the Federation or in Singapore, or is on that day domiciled in the Federation or in Singapore; or (b) is the issue of such a person." ${ }^{26}$ The Merdeka Day refers to August 31, 1957. Thirdly, the view that Islam covers every aspect of Muslim activities including politics is dominating the Malays. In other words, the great majority of Malays still hold that politics and religion are inseparable. Finally, PAS always claims that it always bases on Islam meanwhile UMNO bases on Malay nationalism. Both

\footnotetext{
"Ibid... Dec.1. 1999

"3 Kamarudin Jaafar, 2000, Pilihanraya 1999 dan Masa Depan Polinik Malaysia, Kuala Lumpur, IKDAS, hal. 12

:4 BA Manifesto refers to lkhtisar (Ringkasan/Petikan), MANIFESTO BERSAMA Barisan Alternatif

I" Kamarudin Jaafar, op. cir, hal. 29

:h Legal Resaerch Board, 1988. Federal Constitution (as at 5 th May 1988), Kuala Lumpur, International Law Book Services, ha:.153
} 
parties have to tackle the Islamic issues for political reasons especially for winning the Malay voters in Malaysian general elections. Although the Islamic issues in the present Malaysian political movements are innumerable only four of them are presented here. They are Muslim faith, Muslim ulema, Muslim and non-Muslim political alliance, and Islamic state.

\section{Muslim Faith}

The issue of Muslim faith or belief is discussed in relation with the political movements in Malaysia. The issue at stake is the status of Muslim faith if Muslims support certain political parties. Amir Sarifudin Mansor who interviewed Wan Mokhtar Ahmad, who had been Menteri Besar of Terengganu for 25 years before he was defeated by PAS in the November 1999 general elections, stated that Wan Mokhtar, the head of Terengganu UMNO, was still needed to answer and refute the PAS attacks in its campaigns especially in isu-isu agama (the Islamic religious issues). Amir Sarifuddin asked Wan Mokhtar if he was aware that PAS said that if someone does not vote for PAS, his religious deeds for five years will not be accepted by Allah. Wan Mokhtar replied that such action of PAS indicates that PAS tries to sell cheap the Qurlanic verses for cheap rewards and PAS forgets Allahls punishment for those who sell the Qurlanic versès. Wan Mokhtar said that in this case, PAS exploits the religion for seeking political victory. This also indicates that PAS prefers material gains in this world over Allahls rewards. ${ }^{27}$ In other words, if what Amir Sarifuddin claims about PAS is true, the Malays who do not vote for PAS do not have Muslim faith or belief. Therefore, Allah does not accept their good deeds.

In Kelantan, Ahmad Che Kob, an independent Islamic religious missionary but supporting UMNO, said that there is nothing wrong with the faith of Muslims if they vote for $\mathrm{BN}$ on November 29, 1999. Voting for BN is not wrong and it does not impair or damage the Muslim faith. He stated that PAS and Islam are two different things. He told his audience in the ceramah (the Islamic religiopolitical talk) gathering held at Taman Perumahan Mas, Rantau Panjang, Kelantan on $27^{\text {th }}$ Nov. $1999 . .^{28}$ This indicates that Ahmad Che Kob did not want the Malays to go against UMNO on the basis of Muslim faith. For him, supporting BN is not wrong from Islamic legal and theological perspectives.

Aziz Ishak, a journalist of Utusan, claims that PAS promised Paradise for those who vote for it. He said that due to political ignorance and fanatical attitudes regarding the Paradise promised by PAS for those who vote that party, Datuk Shahnon Ahmad, the writer of SHIT won the Parliamentary seat 
of Sik in Kedah and defeated the BN candidate Datuk Dr. Abdul Hamid Othman. ${ }^{29}$ Dr. Mahathir Mohamad was reported to have said that PAS, in its efforts to win the support from the Muslims, did many things contrary to Islam. For example, PAS guaranteed Paradise for those who vote for PAS although no human being was able to guarantee it. ${ }^{30}$

On the reason why the Terengganu BN or UMNO was defeated by PAS, Dr. Mahathir Mohamad pointed out to the PAS promise of Paradise. He said, "We lost in Terengganu because PAS made efforts to frighten the people and to assure them that those who voted for PAS would go to Paradise had influenced certain people including those working with the Government agencies...." 31

In Pahang, Zulkefli Hamzah reported that its Menteri Besar, Datuk Seri Adnan Yaakob told the press that BN was defeated in eight constituencies because the oppositions especially PAS spread the deviant teaching saying that whoever supported PAS would enter Paradise. That teaching was able to influence the Malay voters. ${ }^{32}$

Rosli Zakaria said that PAS did not make efforts "to stop party members from calling other Muslims who do not support Pas as apostate, or if other Muslims do not vote for PAS, they would not go to heaven."33 Wan Mokhtar Ahmad said that the PAS leaders must be responsible for their judgment that the UMNO members are unbelievers supposedly they become unbelievers because they are in good tenns with the Chinese and Indians in this country. ${ }^{34}$

Idris Umar from PAS who won the State seat in Pahang denied that PAS promised Paradise for those who voted for PAS. Hashim Jasim from PAS who won the State seat in Perlis was also in agreement with Idris Umar. On 8 March 2000 the State Assembly. of Perlis passed "the Islamic Aqidah (Faith) Protection Enactment law... empowering the Syariah courts to prosecute Muslims practicing deviate teachings. The three PAS assemblymen did not support the law as it contradicted true Islamic teachings in terms of penalties for apostates. PAS assembly member Hashim Jasin... hoped that the enactment would not be used against political adversaries. The ruling coalition that also governs Perlis often accuses PAS of abusing Islam to serve its political agenda. It says PAS has issued religious decrees setting a place in heaven for its supporters which PAS consistently denied." 35

sy Utusan Malaysia, Dec.. 1, 1999

30 $\mathrm{Ibid}$.

"Utusan Malaysia, Dec.1, 2000

32 Ibid., Dec. 1, 1999

${ }^{33}$ New Sundan' Times, Apri] 9.2000

${ }^{34}$ Ibid., March 25, 2000

${ }^{35}$ Harakah. April 16-30. 2000 


\section{Muslim Ulema}

The issue of Muslim ulema is their leadership in the Malaysian political movements. The UMNO leaders and supporters consistently asked Malaysians not to support PAS and its ulema leadership because the PAS ulemas are not qualified to become the Muslim ulemas as well as the Malaysian political leaders.

Saroji Mokhtar, the Utusan journalist, for example wrote that the 10th general elections on $29^{\text {th }}$ November 1999 made Kelantan the focus because it was the PAS strongest base, led by those who were called the ulema headed by Nik Abdul Aziz Nik Mat who saw the best opportunity for PAS to give UMNO and BN in Kelantan a crushing defeat. Meanwhile UMNO and BN determined to seize Kelantan from PAS. ${ }^{36}$

Datuk Seri Abdullah Ahmad Badawi, the UMNO Deputy President and the Deputy Prime Minister, said that PAS failed to nominate the ulemas as its candidates for the 1999 general elections because PAS had problem in selecting them. He hoped that the PAS members would realize the internal problems in PAS. He stressed that the PAS struggle was indeed a loss to the nation and Islamic society in comparison with $\mathrm{BN}$, which always gave priority to the people interest and security. ${ }^{37}$ Tengku Razaleigh wanted the Kelantanese to stand up against unprofitable conservatism under the PAS political leadership. He considered the PAS leadership in Kelantan very conservative. The PAS hard core consisting of the Pondok people and the imams did not heed to the call of UMNO but to the call of their PAS leaders who claimed to struggle for Islam. ${ }^{38}$ In other words, the PAS ulemas and their followers in Kelantan were presented as conservatives and their conservatism was a loss for the Kelantanese.

The Arabic word 'ulama' is a plural noun means the learned. If someone refers to Chambers $20^{\text {h }}$ Century Dictionary, New Edition 1983, he finds that "ulema.... the body of professional theologians, expounders of the law, in a Muslim country: a member of such a body." In Malaysia, the Malay term ulama is frequently used for those who graduated in Islamic studies from the Muslim universities in the Middle East such as in Egypt and Saudi Arabia. Among those who are regarded, as the ulema in UMNO are Wan Mokhtar Wan Ahmad, Dr. Mohd. Yusof Nor and Dr. Abdul Hamid Othman. The PAS candidates in Terengganu and Kedah in the November 1999 general elections defeated them. Their defeat is deplorable according to Aziz Ishak who wrote "the defeat of Wan Mokhtar, Hamid Othman and Yusof Noor also unconsciously indicates these three leaders who are the UMNO ulema

\footnotetext{
36 Unusan Malaysia, Nov. 27, 1999

"Ibid. . Nov. 23, 1999

${ }^{3 x}$ Ibid. , Nov. 25, 1999
} 
disappear from the people election power platform." 39 What is said by Aziz Ishak turns to be true in the case of the UMNO leadership in Terengganu. Idris Jusoh who graduated not in Islamic studies was appointed the UMNO leader of Terengganu to replace Wan Mokhtar who had resigned after his defeat in the 1999 general elections. However, in Kedah Dr. Abdul Hamid Othman was reappointed to become the Minister in the Prime Minister's Department after his defeat in the 1999 general elections. Dr. Mahathir Mohamad, Malaysian Prime Minister and the UMNO President lead the UMNO division of Kubang Pasu in Kedah.

Meanwhile some of those who are regarded as the ulema in PAS are Nik Abdul Aziz Nik Mat, Abdul Hadi Awang, Dr. Sanusi Daeng Mariok, Dr. Haron Din, Harun Taib and Fadzil Mohd. Noor. They graduated in Islamic studies from the Muslim universities in the Middle East like the three ulema in UMNO. One of the PAS slogans was "Bersama Kepimpinan Ulama" (Together with the ulema leadership). The poster, which has that slogan also, lists 14 PAS leaders representing 14 states in Malaysia for 1999/2001. The poster was placed in the Kelantan PAS headquarters in Kota Bharu. I read the poster when I visited that office on January 6, 2000.

Dr. Rais Yatim, who rejoined UMNO after the dissolution of S46 in 1996, exhorted the ulemas who supported UMNO and Malaysia Government to speak up against the Islamic teachings spread by the PAS ulemas. After he won the Parliamentary seat in Negeri Sembilan in the 1999 general elections, Dr. Rais Yatim was appointed the Minister in the Prime Minister's Department. He was reported to have said, "PAS is teaching Muslims to hate other Muslims. This kind of teaching may end up as a belief. By then it will be too late for the country. The problem has to be arrested immediately".40

Nik Abdul Aziz Nik Mat, the PAS General Advisor or Mursyidul Am PAS, argued that the ulema are capable of being the Malaysian political leaders since they have acquired higher knowledge in various fields and many of them graduated from higher learning institutions and supported by academicians and professionals. Due to many ulema in PAS, its opportunity nowadays is very clear in the meantime the opportunity of UMNO is darken, and darken. If the ulema do not know the administrative matters, they would easily learn them in a threemonth course. ${ }^{41}$ Nik Aziz has advocated the positive view regarding the Muslim ulema and their political participation in PAS. His positive view is contrary to the negative view from those who see that the PAS ulemas are unqualified to become Malaysian political leaders as well as Muslim utema.

\footnotetext{
ss Ibid. Dec. 1, 1999

"Sunday Star. April 2. 2000

\& Utusair Malaysia, August 12. 1999
} 
Wan Ramli Wan Muhamad interviewed Prof. Dr. Abdul Hamid Abdullah and asked his opinion about Nik Abdul Aziz Nik Mat, the PAS General Advisor and the PAS leader of Kelantan. The Professor was reported to have said that Nik Abdul Aziz was not qualified to become the Malay and Islamic leader because he did not understand the reality of his own race. The Malays especially those in Kelantan should reject his leadership. He did not want to protect the Malay privileges after PAS had cooperated with DAP. Moreover, that Professor was reported to have suggested that PAS should be banned and only UMNO should be kept alive. ${ }^{42}$

Tengku Razaleigh Hamzah discredited Nik Aziz on the subject of Paradise and Hell. He was reported to have said, "Why is Nik Aziz forever harping on heaven and hell? He is not the guardian of heaven gate. Even Nik Aziz himself cannot be sure that he will go to heaven. Only the Almighty will decide." 43

As regard to Abdul Hadi Awang who is regarded as the Islamic religious scholar by PAS, the UMNO members do not see him capable in politics and administration. Jaceline Tan wrote, "The UMNO side likes to portray Abdul Hadi as little more than a skilled preacher with scant understanding of the art of government." 44

UMNO is said to have neglected its ulema due to "the influx of corporate leaders into UMNO since the early 1990s". Since then UMNO "had alienated teachers and religious-minded grassroots leaders who had been the party's traditional source of support. What made matters worse was those corporate people tried to put on an Islamic image to win the hearts of the kampunglevel party members. That gave PAS another reason to portray UMNO as being capitalist-invested and thus making a mockery of the religion." ${ }^{45}$ UMNO is called to handle the issue of Muslim ulema "as PAS leaders have convinced some Malays that their ulamak are the only true leaders that Muslims ought to follow." 46 For Dr. Rais Yatim, "PAS leaders masquerading as ulamak have been issuing fatwa (religious edict) on their own even though such a role is solely reserved for state mufti (head of religious department or council) and the National Fatwa Council, a non-political religious body whose members are ulamak and mufti." 47

I tend to agree with Wan Hamidi Hamid about the important role played by the Muslim ulema in Malay society. He wrote "The ulamak have played

\footnotetext{
Ibid.. Nov. 27, 1999

${ }^{33}$ New Sunday Times, Nov. 28, 1999

${ }^{4}$ Ibid. . April 9.2000

sts Sunday Star, April 2, 2000

st Ibid.

${ }^{47}$ lbid
} 
an important role in Malay society for the last 500 years and will continue to do so." He further stressed that "In reality PAS ulamak are as much politicians as UMNO's, but the Malays seem to be more attracted to the political rhetoric of people with religious credentials." ${ }^{48}$ The standard Malay spelling for ulema is ulama, not ulamak as in the quotations. ${ }^{49}$

In order to attract Muslim ulema, Islamic religious teachers and imams to support UNMO and BN in Kelantan, the BN manifesto for Kelantan promised to defend and look after their interests. ${ }^{50}$ What was clear that the Kelantanese voters did not pay much attention to the BN manifestos for Kelantan. Therefore, BN was unable to seize Kelantan from PAS in the 1999 general elections.

Iskandar Astar blamed the UMNO ulema for the serious defeat of the UMNO candidates in the 1999 general elections. He stressed that the ulema in UMNO did nothing to counter attacks the PAS propagandas against UMNO and the Government. ${ }^{\text {s1 }}$

\section{Muslim and Non-Muslim Political Alliance}

The issue of Muslim and non-Muslim political alliance is still prevalent in Malaysian politics. PAS used to ask the Malay voters to reject UMNO for its alliance with MCA, MIC and GERAKAN, three non-Muslim parties. In the booklet published for the 1995 general elections, it was written that it is unreasonable for the Kelantanese people to change the dogma to support Barisan Nasional which is openly dominated by the secular and fanatical party UMNO (Malay) together with MCA (Chinese), MIC (Indians) and GERAKAN (Chinese). Because all we know that those parties from Barisan Nasional especially UMNO clearly reject any effort to implement Islam (including $h u d u d$ ) in nation administration. ${ }^{52}$

However, the booklet published for the 1999 general elections does not have such political thought regarding the political alliance between Muslims and non-Muslims. ${ }^{53}$ This is due to the new attitude of PAS towards DAP. Zin Mahmud wrote that the opposition alliance was formed between PAS, DAP, KEADILAN, and PRM. It was the first time in history, PAS was able to officially cooperate with DAP. It was accepted by the PAS supporters.

\footnotetext{
In

"Wewan Bahasa dan Pustaka. 1988. Daftar Ejaan Rumi Bahasa Malạsia. 2nd Edition. Kuala Lumpur. Dewan Bahasa dan Pustáka

-Unusan Malorsia. Nov. 26, 1999

“Mingzuan Malaysia. Jan. 2, 2000

sAngkatan Perpaduan Ummah Negerj Kelantan, 1995, Kelantan Membangun Bersama Islam: Program Angkatan Perpaduan Ummah Negeri Kelantan Pilthan Raja Umum 1995, Kelantan, Angkatan Perpaduan Ummah Negeri Kelantan. hal. 6

* Badan Perhubungan PAS Negeri Kelantan. 1999. Prograin PAS Negeri Kelantan Pilihan Raya Umum 1999, Kelantan: Badan Perhubungan PAS Negeri Kelantan
} 
This indicated a new thought among the PAS supporters for their willingness to cooperate with DAP. The 1999 general elections granted PAS the great victory since PAS was able to consolidate in Kelantan, won Terengganu and penetrated into the traditional UMNO areas in Kedah, Perak, Penang, Selangor and Pahang. ${ }^{54}$

Regarding the aim of the opposition political alliance, Lim Kit Siang stressed "Alternative Front-parties have come together not to share the spoils of power, but to break the Barisan Nasional political hegemony to restore justice, freedom, democracy and good governance in Malaysia. ${ }^{n 5}$ PAS did not see any wrong from Islamic law as regard to its alliance with DAP. To legitimize and justify his agreement with DAP, PAS referred to the al-fudul agreement between the Prophet Muhammad and the non-Muslims in the classical Muslim history..$^{56}$ Moreover, PAS justified that its alliance with nonMuslims in political matters does not transgress any Islamic law. The Legal Committee of the Kelantanese Islamic Religious Council issued the religious ruling permitting Muslims to associate with infidels, to negotiate, discuss and compromise with them for the purpose of governing a nation. That religious ruling was issued on September 14, 1963..$^{57}$ PAS considered its alliance with $\mathrm{DAP}$ as a political agreement or al-tahaluf al-sijasi to push down the National Front. ${ }^{58}$

UMNO and other parties in BN did not like the political corporation between PAS and DAP. Datuk Seri Dr. Ling Liong Sik, the MCA President, urged "Chinese Malaysians to vote for the Barisan Nasional" and his consistent message delivered to his audiences "especially in places which were considered DAP strongholds" was "A vote for the DAP is a vote for Nik Aziz". The corporation between PAS and DAP was used by MCA to "create some uneasiness, if not outright fear" among the Chinese voters. ${ }^{59}$ Lim Kit Siang, the DAP Secretary-General, was reported to have said that his party would lose greatly due to the PAS factor and some of the PAS leaders were aware that some of the Malays would reject PAS due to its cooperation with DAP. ${ }^{60}$ Finally Lim Kit Siang lost to the GERAKAN candidate Chia Kwang Chye, the GERAKAN Secretary-General, in their political contest for the Parliamentary seat of Bukit Bendera in Penang in the 1999 general elections. According to Norzahizan Ismail, the number of the

\footnotetext{
4 Unsan Malaysio, Dec. 1, 1999

ss Kamarul Zaman Haji Yusoff, 1999, Pejiuangan Penuh Cabaran, Kota Bharu, Kelantan, Qamar Publishing, hal. 123

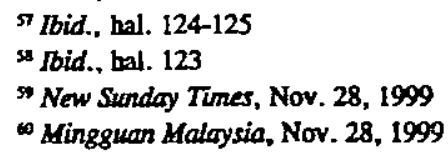


registered voters for Bukit Bendera Parliamentary seat was 70,818 consisting of 10,822 Malays, 51,967 Chinese, 6,164 Indians and 1,415 other ethnics. ${ }^{61}$ Lim Kit Siang became the DAP Chairman after his defeat in the 1999 general elections, following the resignation of Dr.Chen Man Hin from the DAP chairmanship.

Tengku Razaleigh Hamzah was reported to have said that Nik Aziz legitimized the PAS-DAP relationship. He said that the Kelantanese voters would reject PAS due to its coalition with DAP. ${ }^{62}$ Prof. Datuk Dr. Syed Hussein Alatas saw the opposition alliance was formed solely to win the general elections and the marriage between PAS and DAP was a mut 'ah marriage for the sake of the general elections. They surely would soon separate after the general elections since both parties had different political goals. ${ }^{63}$

According to Joceline Tan, "Malaysians were not ready for the prospect of PAS, KEADILAN, DAP and PRM being in charge." Their loose coalition could not compete with $\mathrm{BN}$ in forming and managing a government although they pointed out the faults and shortcomings of $\mathrm{BN}$, the ruling party. 64

\section{Islamic State}

The issue of Islamic state is another point of contention between PAS, UMNO, MCA and DAP. UMNO and MCA exhorted and appealed to Malaysians not to lend their support to PAS and DAP because both parties planned to establish an Islamic state in Malaysia or to make Malaysia an Islamic state. It was a crucial, provocative and controversial issue for the 1999 Małaysian general elections.

In 1980. Funston wrote "A more fundamental difference, however, centered on PAS's advocacy of an Islamic state and UMNO's rejection of this concept. UMNO leaders repeatedly declared that Malaysia could never become an Islamic state,..." ${ }^{n 6}$

Datuk Hishamuddin Tun Hussein, the deputy leader of UMNO youth, challenged PAS to explain its stand on the hudud law and the Islamic state and asked Malaysians not give their support to the opposition parties namely DAP, PAS, KEADILAN and PRM because they had different dreams. Their sole purpose was to destroy the Government, the harmony, the peace and

61 Bid.

62 Ibid.

ovid., Oct. 31, 1999)

New Sunday Times, Nov. 28, 1999

s N.J. Funston, 1980, Maloy Politics in Malaysia: A Sucty of the Unired Malays Narional Organisation and Party Islam, Kuala Lumpur, Heinemann Books (Asia) Ltd., hal. 145

to Unusan Malaysia, Nov. 16, 1999 
stability and the Bumiputeras' special privileges. ${ }^{66}$ Datuk Mustafa Muhamad, the second Minister of Finance, said that the Government of National Front was more Islamic than PAS because the Government had implemented many development projects for Muslims, and unlike the oppositions who know only talking. Some of the projects were Islamic bank and Islamic insurance. ${ }^{67}$ In its manifesto for the 1999 general elections, BN made mention the two Islamic projects namely Islamic bank and Islamic insurance. ${ }^{68}$

Although the manifesto issued by BA did not include the establishment of an Islamic state in Malaysia, BN fully and intentionally exploited the issue of Islamic state. According to Joceline Tan, the opposition parties in the 1999 general elections cried "foul about the way the $\mathrm{BN}$ has played up their divergent stand on the Islamic State issue." DAP unequivocally rejected the Islamic state issue but PAS in Kelantan and Terengganu did not reject it. "The argument that PAS would not have the clout to amend the Constitution in favor of an Islamic State does not cut any ice with many non-Malays." 69 MCA asked the Chinese voters to reject DAP for the reason that DAP support PAS and the Islamic state in Malaysia. "Thus, in non-Malay areas, the MCA has been campaigning along the line of "A vote for DAP is a vote for an Islamic State"70

In Kelantan, Tengku Razaleigh Hamzah, the Kelantan UMNO leader, was reported to have said that PAS insisted on the formation of an Islamic state but Nik Aziz was continuously vacillated because he wanted to captivate the Chinese whom he thought had sided with PAS. Tengku Razaleigh was commenting on the report saying that Nik Aziz said that the PAS constitution does not target an Islamic state, but an Islamic society. Therefore, Tengku Razaleigh called on the Kelantanese voters to reject PAS since its leader's stand was easily changeable. ${ }^{71}$ Tengku Razaleigh called on Nik Aziz "to stop insulting the intelligence of the people over the Islamic state issue. He was commenting on Nik Aziz's statement yesterday that PAS's objective was actually an Islamic society and not an Islamic state." Tengku Razaleigh dismissed Nik Aziz's explanation and stressed that "Nik Aziz and PAS had often declared to all and sundry they would never compromise on the matter" ${ }^{n}$

DAP did not deny that it supported PAS but it did not support the Islamic state, Lim Kit Siang was reported on October 30, 1999 to have said that

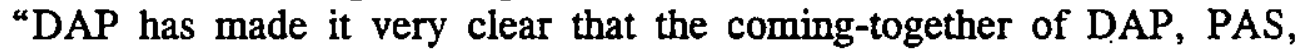

\footnotetext{
${ }^{67}$ Ibid.

${ }^{64}$ Kamarudin, op, cit., hal. 66

*o New Sunday Times, Nov. 28, 1999

" Ibid.

"Mingguan Malaysia, Nov. 28, 1999

${ }^{7}$ New Sunday Tume, Nov. 28, 1999
} 
KeADILan and PRM is not to establish an Islamic state, but to restore justice, freedom, democracy and good governance, and the DAP has made it very clear to PAS leaders that the DAP opposition to an Islamic state in Malaysia is constant and consistent. "73 Lim Kit Siang expected Islam to bring moderation, tolerance and democracy to Malaysians. He was reported as saying, "Political Islam in Malaysia represents the face of moderation, tolerance and democracy." ${ }^{4}$ Dr. Chen Man Hin, the DAP chairman prior to Lim Kit Siang, was reported to have said that the defeat of the DAP leaders including he himself, Lim Kit Siang and Karpal Singh was due to the issue of Islamic state advocated by PAS. The issue frightened the Chinese voters. ${ }^{75}$

Joceline Tan reported that "The average Chinese Malaysian, rightly or wrongly, has come to associate an Islamic State with restrictions on alcohol, gambling, entertainment outlets, women's attire and inter-mingling between the sexes... Many Chinese women, for instance, find PAS attitudes too feudalistic and retrogressive for their liking." Joceline Tan also said that during the 1999 general elections, the MCA exploitation of the concept of an Islamic state "to the fullest against its arch-enemy, the DAP, ..."76

The issue of Islamic state in Malaysia helped the National Front especially the Chinese parties namely MCA and GERAKAN to frighten the Chinese voters from giving their votes to the opposition parties especially the Chinese party DAP.

\section{Closing}

In conclusion we may say that the Islamic issues especially the four issues mentioned above are very influential for the political movements in Malaysia to exploit them for their own sides and benefits.

\footnotetext{
3 Kamarul Zaman Haji Yusoff, op. cit., hal. 123

7 Sunday Srar, April 2, 2000

7 Utusan Maloysia, Dec. 1, 2000

New Senday Tures, April 16, 2000
} 


\section{REFERENCES}

Andaya, Barbara Watson and Andaya, Leornard Y., 1986, A History of Malaysia. Houndmills: Macmillan Education Ltd.

Angkatan Perpaduan Ummah Negeri Kelantan, 1995, Kelantan Membangun Bersama Islam [:] Program Angkatan Perpaduan Ummah Negeri Kelantan Pilihan Raya Umum 1995. Kelantan: Angkatan Perpaduan Ummah Negeri Kelantan.

BA Manifesto refers to Ikhtisar (Ringkasan/Petikan) MANIFESTO BERSAMA Barisan Alternatif. It has four pages.

Badan Perhubungan PAS Negeri Kelantan (BPPNK), 1999, Program PAS Negeri Kelantan Pilihan Raya Umum 1999. Kelantan: Badan Perhubungan PAS Negeri Kelantan.

Dewan Bahasa dan Pustaka (DBP), 1988, Daftar Ejaan Rumi Bahasa Malaysia. $2^{\text {nd }}$ Edition. Kuala Lumpur: Dewan Bahasa dan Pustaka.

Department of Statistics Malaysia, 1995, Laporan Am Banci Penduduk (General Report of the Population Census), Vol. 1. Kuala Lumpur: Department of Statistics Malaysia.

Funston, N.J, 1980, Malay Politics in Malaysia : A Study of the United Malays National Organisation and Party Islam. Kuala Lumpur: Heinemann Educational Books (Asia) Ltd.

Harakah, April, 16-30, 2000

Ibu Pejabat Barisan Nasional. (IPB), 1995, Barisan Nasional Berwawasan Adil Efisien. Kuala Lumpur: Ibu Pejabat Barisan Nasiona. This brochure was issued and distributed by BN for the 1995 Malaysian general elections. It contains BN promises to Malaysian voters.

Ibrahim, Safie Bin, 1981, The Islamic Party of Malaysia: Its Formative Stages and Ideology. Pasir Puteh, Kelantan: Nuawi bin Ismail.

Jaafar, Kamarudin, 2000, Pilihanraya 1999 dan Masa Depan Politik Malaysia, 'Kuala Lumpur: IKDAS

Legal Research Board, 1988, Federal Constitution (As At $5^{\text {th }}$ May 1988). Kuala Lumpur: International Law Book Services.

Mauzy, Diane K. 1986. "The 1982 General Elections in Malaysia: A Mandate for Change?" In Readings in Malaysian Politics, pp. 3-24. Edited by Bruce Gale. Petaling Jaya: Pelanduk Publications. 
Mingguan Malaysia, October 31, 1999

, November, 28, 1999.

, January 2,2000

New Straits Times, December 9, 1999

, November 28, 1999

, April 9, 2000

New Sunday Times, April 16, 2000

Paul Chang Ming Phang, 1975, Perkembangan Pelajaran dalam Masyarakat Berbilang Kaum Kajian Kes Malaysia. Kuala Lumpur: Dewan Bahasa dan Pustaka.

Pejabat Barisan Nasional Negeri Kelantan (PBNNK), 1995, Barisan Nasional Membangun Kelantan Negeri Contoh. This brochure was published and distributed for the 1995 Malaysian general elections in the State of Kelantan. It contains BN promises for the Kelantanese voters if they vote for BN to rule Kelantan.

Sunday Star, April 2, 2000,

Utusan Malaysia, August 12, 1999

, November 16, 23, 25, 26, 271999

, December 1, 1999

, March 25, 2000

Yusoff, Kamarul Zaman Haji, 1999, Perjuangan Penuh Cabaran. Kota Bharu, Kelantan, Qamar Publishing 